\title{
Conspiracy and Contemporary History: Revisiting MI5 and the Wilson Plot[s]
}

'I was an old fashioned radical liberal and I didn't believe in all this secrecy. He [Prime Minister James Callaghan] remarked that if I started inquiries I'd only drive the Intelligence Service underground. Well, that was rich, given that they were already underground.'

Tony Benn, Conflict of Interest. Diaries 1977-80 (London: Arrow 1991), 379-80, diary entry, October 251978.

'Every Prime Minister has his own style. But he must know all that is going on.'

Statement by the Prime Minister to the Cabinet, 16 March 1976, on his resignation in Harold Wilson, Final Term. The Labour Government 1974-1976 (London: Weidenfeld and Nicholson, 1979), 303.

\begin{abstract}
This article examines the debates which have taken place again recently concerning the long standing idea of a plot in the 1970s against the elected Labour government under Prime Minister Harold Wilson. Two television programmes in 2006 and Christopher Andrew's 2009 official history of the UK Security Service (MI5) discussed the plot. Andrew's history dismissed the possibility of a a conspiracy out of hand. This article critiques this approach and also discusses the continuing power of ideas of right wing plotting against Wilson. The plots remain an interesting and unresolved debate in contemporary intelligence history.
\end{abstract}

\section{Keywords}

Harold Wilson, MI5, conspiracy, intelligence, British history 


\section{Introduction}

The Wilson Plot[s] concern a series of attempts by right wing figures in the British establishment to undermine Harold Wilson, Prime Minister of the Labour governments in the period 1964-70 and 1974-76. Two main 'plots' are alleged to have taken place, one in 1968 and a more protracted series of moves in the mid-1970s, the result of which may have been to force Wilson's resignation as Prime Minister. This article deals with the plotting of the mid-1970s which was said to have involved serving and former intelligence officers. The plots and the debates about them are an important reflection of British politics and they represent a number of viewpoints or narratives about the British state that still have the power to generate debate and divide opinion. For example in 2006 a documentary and a 'faction' entertainment on the two major terrestrial TV channels in the UK focused directly on the issue of whether the security services had manoeuvred against Wilson in the 1970s, and in 2009 historian Christopher Andrew's official history of MI5, 'The Defence of the Realm' included a chapter specifically debunking the idea that there was any plot against Wilson in the 1970s. This provoked further debate in the media and once again highlighted the importance of intelligence as a 'missing dimension' in history. ${ }^{1}$ This article examines the continuing controversy about the actions of MI5, prompted by Andrew's history. It argues that Andrew's argument is detailed but flawed both analytically and empirically. The characterisation of Harold Wilson as paranoid does not take account of the political context of the time, which was characterised by a paranoid political style generally which applied to both left and right (including MI5 itself). The suspicion of Wilson and others towards the unlawful activities of the security services and other right wing figures resulted from concrete domestic and international developments discussed in more detail below. Andrew is correct to be sceptical, and there remains limited evidence of a 'plot,' if a plot is defined as a tightly organised high level conspiracy with a detailed plan. However there is evidence of a conspiracy: a loosely connected series of unlawful manoeuvres against an elected government by a group of likeminded figures.

\footnotetext{
${ }^{1}$ Christopher Andrew and David Dilks, The Missing Dimension: Governments and Intelligence Communities in the Twentieth Century (London: Macmillan, 1984).
} 


\section{Parallel government in British culture}

Searching for 'Harold Wilson coup' in Google gives 159,000 results and 'Harold Wilson conspiracy theories' gives 84,100 results $^{2}$ reflecting the continuing interest the topic. This in turn reflects the continuing idea of conspiracy as an explanation for certain political developments in the UK, particularly the case with regard to the 1970s, a period Francis Wheen has termed Strange Days Indeed, when ideas of plots and conspiracies by right and left groups were evident at all levels of British society. ${ }^{3}$ This legacy was strengthened with the dominance of Margaret Thatcher and the Conservatives throughout the 1980s, and the allegations of intelligence and security force misdeeds in the UK and particularly in Northern Ireland that accompanied that period. A core idea of critics was that a network of power existed which functioned behind the formal institutions of British politics.

In the 1980s and 1990s the journal Lobster consistently argued for the power of a parallel right wing power structure. In a plethora of articles it examined the networks linking defence, intelligence, industry, finance and the media in the UK, and the founders of Lobster have continued to produce detailed work examining the operation of a parallel state. ${ }^{4}$ Similarly the diaries of certain cabinet Ministers such as Tony Benn pointed to what he called a secret or shadow state which manoeuvred against those who opposed nuclear power. ${ }^{5}$ The history of Northern Ireland is replete (indeed is overburdened) with works alleging that the British state operated death squads in Northern Ireland either directly or by using loyalist paramilitaries to do their dirty work for them. ${ }^{6}$ Whilst those stories might be overblown ${ }^{7}$ there were some strange activities on the part of British military intelligence in

\footnotetext{
${ }^{2}$ Searches conducted August 242013.

${ }^{3}$ Francis Wheen, Strange Days Indeed (London: Fourth Estate, 2009).

${ }^{4}$ One of the founders, Stephen Dorril took up a post at a UK university and produced a remarkably detailed history of MI6 from its formation up until the 1990s.

${ }^{5}$ Tony Benn, Conflict of Interest. Diaries 1977-80 (London: Arrow,1991). Benn was Minister of Energy in the Labour government 1974-79. See also Tony Benn, 'The Case for Dismantling the Secret State', New Left Review 190 (1991), 127-130.

${ }^{6}$ For conspiratorial views see Sean McPhilemy, The Committee: Political Assassination in Northern Ireland (Boulder: Roberts Rinehart, 1998); Justin O'Brien, Killing Finucane: Murder in Defence of the Realm (Dublin: Gill and Macmillan, 2005); Brendan O’Neill, 'Pat Finucane wasn't the only victim of state terror' Spiked December 132012 http://www.spiked-online.com/newsite/article/13168 (accessed September 29 2013)

${ }^{7}$ For a critique of McPhilemy but one which also in effect applies to much conspiracy theorising over Northern Ireland see Steve Bruce, "Loyalist Assassination and Police Collusion in Northern Ireland: An Extended Critique of Sean McPhilemy’s The Committee'," Studies in Conflict and Terrorism 23 No.1 (2000): 61-80.
} 
the early 1970 s as they struggled to control the conflict. ${ }^{8}$ Some of the issues raised by critics or observers of the secret state were investigated in TV programmes in the 1980s such as After Dark, World in Action, This Week, Panorama and the controversial BBC series Secret Society covering defence, law and order and security and surveillance. ${ }^{9}$ This kind of critique also appeared in fictional form in the Chris Mullin novel 'A Very British Coup' (later made into a successful TV series of the 1980s which was then re-made in 2013 as 'Secret State,' both by Channel 4) while the 1980s also saw a series of classic TV dramas and films directly dealing with the shadow state. ${ }^{10}$

This belief in a parallel power structure is prevalent in the UK partly because it has much tighter rules on declassification and freedom of information than the USA. Documents are generally classified for 30 years and then carefully pruned before being released. Therefore when documents are released they tend to provoke public debate about what they reveal and what may be held back. For example documents opened to the public from the 1970s show that the UK government maintained a series of secret channels of communication to the republican movement (the Provisional IRA and Sinn Féin) despite consistently saying that they would never talk to terrorists. In addition documents earlier revealed that British servicemen were subject to chemical tests at Porton Down over decades. Many did not give full consent because they were told the tests for were the common cold when in fact they were being exposed to chemicals which might assist the British state in its biological defence/warfare programmes. For years the authorities denied even the existence of the research facility at Porton

\footnotetext{
${ }^{8}$ Paul Foot, Who Framed Colin Wallace (London :Macmillan, 1989); Jon Moran, From Northern Ireland to Afghanistan. British military intelligence operations, ethics and human rights (Farnham: Ashgate, 2013) ${ }_{9}$ After Dark was an open ended discussion programme which regularly dealt with security, official secrets and intelligence during its run on Channel 4 from 1989-1991; the 6 part BBC series Secret Society provoked a public debate when one of its programmes on the UK's Zircon spy satellite project led to a raid by police Special Branch on the BBC and journalist Duncan Campbell's home and the seizure of the programme. World in Action was an ITV investigative reporting series which ran from the 1960s to the 1980s and regularly featured security, intelligence and other issues. Its broadcast 'The Spy Who Never Was' (1984) first aired Peter Wright's allegations about a plot against Harold Wilson's government. Another ITV documentary series, This Week made 'Death on the Rock' (1989) examining the SAS shooting dead three IRA paramilitaries who were planning to blow up a British military band on Gibraltar a programme that was particularly controversial for challenging the security agencies version of events.

${ }^{10}$ Chris Mullin's novel A Very British Coup was published in 1982; Edge of Darkness, a nuclear conspiracy thriller was broadcast on BBC in 1985; and the film Defence of the Realm, a conspiracy thriller concerning US nuclear weapons on British soil and directed by David Drury was released in 1987; Hidden Agenda, a conspiracy thriller centred on Northern Ireland was directed by Ken Loach and released in 1991.
} 
Down. ${ }^{11}$ Conspiracy theories have more space to develop in the gap left by the general secrecy of the British state and the limited revelations which do take place after 30 years or after long term campaigns by journalists. ${ }^{12}$

If the televisual and literary culture of the 1980s and 1990s took a sceptical view of the security services and the secret state, this changed somewhat after $9 / 11$ when the security services became viewed in a generally positive light via dramas such as 'Spooks', 'Strikeback' and so forth. ${ }^{13}$ Nevertheless if the Wilson controversy highlights a historical period when political paranoia was rife it also still links to the contemporary period: David Peace wrote a series of powerful novels covering networks of police and public corruption and violence in the north of England in the 1970s and 1980s and the intelligence services involvement in the Miner's Strike of 1984-85. Published in the 2000s, these novels were successful and were later made into a television series in $2009 .{ }^{14}$ Meanwhile the Wikileaks and the NSA revelations show to critics in the UK that a parallel national security state is still in operation and is becoming more technologically sophisticated. ${ }^{15}$

Therefore it was not surprising that after two documentaries in 2006 which discussed the plotting against Harold Wilson, debate re-emerged. Journalist Jonathan Freedland, no believer in conspiracy theories called for an inquiry after viewing the BBC documentary 'The Wilson Plot':

'It sounds fantastic, almost comic. But watch Greenwood talk of setting up his own private army in 1974-75. Listen to the former intelligence officer Brian Crozier admit his lobbying of the army, how they "seriously considered the possibility of a military takeover". Watch the

\footnotetext{
${ }^{11}$ Rob Evans, 'The Past Porton Down Can’t Hide,' Guardian, May 6, 2004.

${ }^{12}$ For relatively differing views on this see Christopher Moran, Classified. Secrecy and the State in Modern Britain (Cambridge: Cambridge University Press 2012) which argues the state has struggled to keep secrets in the post war period and Heather Brooke, The Silent State (London: Windmill 2011) who argues that the British state remains a remarkably secretive organisation, especially when viewed comparatively.

${ }^{13}$ Spooks was a BBC spy series based around MI5 and ran from 2002-2011. It was even quoted by Dame Eliza Manningham-Buller then head of MI5 in a speech emphasising that the almost superhuman abilities of Spooks' MI5 agents were not a guide to real life. BBC, "MI5 tracking '30 UK terror plots,' $B B C$ News November 10 , 2006 http://news.bbc.co.uk/1/hi/uk/6134516.stm (accessed September 25 2013); Strikeback is a drama currently running on Sky based around the exploits of a UK special forces and intelligence team hunting terrorists.

${ }^{14}$ David Peace, 1974 (London: Serpent's Tail 2000); 1977 (London: Serpent's Tail 2001); 1980 (London: Serpent's Tail 2001); 1983 (London: Serpent's Tail 2002); GB84 (London: Faber and Faber 2005)

${ }^{15}$ Iraq War logs http://wikileaks.org/irq/; Secret US Embassy Cables http://wikileaks.org/cablegate.html (accessed October 14 2013) James Vincent, 'Encryption protocols compromised by NSA and GCHQ, according to leaked Edward Snowden documents,' Independent September 6, 2013.
} 
archive footage of troop manoeuvres at Heathrow, billed as a routine exercise but about which Wilson was never informed - and which he interpreted as a show of strength, a warning, even a rehearsal for a coup. Listen to the voice of Wilson, who five weeks after resigning summoned two BBC journalists to tell them, secretly, of the plot. ${ }^{, 16}$

The Marxist left, no friend of Wilson to say the least also discussed again the prospects of a 'Chilean solution' to Britain's political problems in the 1970s. Following the 2006 documentary the Socialist Party of Britain republished a series of articles on the threat from the state that had appeared in its forerunner organisation Militant's paper in the early 1980s. ${ }^{17}$

The quasi fascist organisation Stormfront also discussed the programmes, with one of the contributors linking the 1970s plotting with another previous 1968 conspiracy. According to this reasoning the moves against Wilson were actually part of some sort of internal Jewish manoeuvring involving press, security and politicians, ending with the view that 'There's a hell of a lot more Jewish folk moving and shaking at the top table in this country than most people realise, don't you think? ${ }^{18}$

Thus the Wilson period provides a platform on which various organisations can still place their questions or conspiracy theories, be they mainstream, radical or racist. The power of the belief in a plot against Wilson is such that the MI5 website has a dedicated page refuting the conspiracy theory. ${ }^{19}$

\section{Discussing and dismissing the Wilson Plot}

Christopher Andrew in his official history of MI5 argues that Security Service officers did not plot against Wilson and in fact were committed to the rule of law. For Andrew, Wilson's character was an important part of the genesis of the plot idea. He surrounded himself with a number of figures who were seen as having suspect connections with the USSR or displaying risky personal characteristics.

\footnotetext{
${ }^{16}$ Brian Crozier was a right wing journalist with links to politicians and the security services. Retired Major Alexander Greenwood was a supporter of the private organisations being established by the right. Jonathan Freedland, 'Enough of this cover-up: the Wilson plot was our Watergate,' Guardian March 15, 2006. Freedland called for an inquiry into the plot.

17 'The State: A warning to the labour movement' http://www.socialistparty.org.uk/pamphlets/state/ (accessed August 15 2013)

18 'How Close did Britain Come to a Coup d'état in 1974?' (2006) http://www.stormfront.org/forum/t346792/

${ }^{19}$ https://www.mi5.gov.uk/home/mi5-history/the-cold-war/the-wilson-plot.html (accessed August 16 2013)
} 
Wilson was close to Joseph Kagan, a Lithuanian businessman who was a long term resident in the UK and the Prime Minister regularly wore Kagan's Gannex coats in public. However, according to the Security Service archives, the KGB was grooming Joseph Kagan to provide information on Wilson and his inner advisors. The conduit for this was a Lithuanian KGB officer resident in London, Richardas Vaygauskas. MI5 had informed Wilson of this in 1972 but he continued to regularly meet with Kagan. ${ }^{20}$ Wilson also knew Rudy Sternberg, who like Kagan made money trading with the Soviet Bloc. MI5 thought that whilst he was not an agent, Sternberg was vulnerable to Soviet pressure. ${ }^{21}$ Andrew also goes into detail on another acquaintance of Wilson's, Harry Kissin who also worked in East-West trade and regularly used prostitutes. ${ }^{22}$ Andrew argues 'Why Wilson was attracted to such dubious characters still remains something of a mystery.' His argument here is implicit: Wilson was at the centre of a crowd of suspect individuals who had contacts with the Soviets. If there was any plotting going on, he was the risk.

Another part of Wilson's character was his paranoia, which increased through the 1960s and 1970s. Even close colleagues like Lord Donoughue (Wilson's Policy Advisor from 1974-76) confirmed this character trait:

'He was obsessed almost paranoid about politicians plotting and especially about the press being out to get him and damage him. But it was actually true some politicians, not many, were plotting against him but much of the press was plotting to damage him... so he had a very sensitive nature that reacted to what was going on. ${ }^{, 23}$

MI5 itself also focuses attention onto Wilson's increasing paranoia by quoting Wilson's biographer:

'His official biographer Philip Ziegler relates an account of Wilson's caution in the lavatory in Number 10, where "the Prime Minister pointed at the electric light fitting and made an

\footnotetext{
${ }^{20}$ Christopher Andrew, The Defence of the Realm. The Authorised History of MI5 (London: Penguin, 2009), $627-28$

${ }^{21}$ Andrew, Defence of the Realm, 630.

${ }^{22}$ Andrew, Defence of the Realm, 631-32.

${ }^{23}$ 'Wilson's World,' BBC Parliament, broadcast August 272013.
} 
exaggerated gesture of caution, putting his finger to his lips and indicating that confidential talk would be unsafe." 24

Wilson was so concerned about plots against him that in 1976 he called journalists Barrie Penrose and Roger Courtiour to meet him. In their first meeting with Wilson he said: "Occasionally when we meet I might tell you to go to the Charing Cross Road and kick a blind man standing on the corner. That blind man may tell you something, lead you somewhere." ${ }^{25}$ This has been one of the more unfortunate quotes in intelligence history as it has been used by writers on the subject to present the idea of antiWilson plotting as being absurd. Indeed, Andrew states: 'no holder of that office has given a stranger interview' ${ }^{26}$ and his damning conclusion is that 'Conspiracy theorists are inherently unfitted for the ultimate responsibility which fell to Wilson as prime minister for the management of the British intelligence community. ${ }^{27}$

In sum, considering Wilson's personal and political psychology there is in practice little evidence for a plot of any kind. The main other fuel for the allegations was the book published in the late 1980s by former MI5 officer Peter Wright who argued that a group of discontented MI5 officers were prepared to join him in a plot to oust Wilson. ${ }^{28}$ But in later interviews he gradually withdrew from his statements arguing that the original 30 officers who supported him were in reality only one. ${ }^{29}$

Finally Andrew argues that the plot was investigated thoroughly. In response to the debate and national media headlines created by Wright's book and by the British government's futile efforts to prevent its publication, the MI5 Director General Anthony Duff ordered a, 'stringent internal inquiry which examined all relevant files and interviewed all relevant Security Service officers, both serving and retired, concluded unequivocally that no member of the Service had been involved in the

\footnotetext{
${ }^{24} \mathrm{https} / / / \mathrm{www} . \mathrm{mi} 5 . g o v \cdot u k /$ home/mi5-history/the-cold-war/the-wilson-plot.html (accessed August 10 2013)

${ }^{25}$ Brian Wheeler, "Wilson 'plot': the secret tapes," BBC News March 9, 2006 http://news.bbc.co.uk/1/hi/uk_politics/4789060.stm (accessed August 10 2013)

${ }^{26}$ Christopher Andrew, The Defence of the Realm. The Authorised History of MI5 (London: Penguin, 2009), 639.

${ }^{27}$ Andrew, Defence of the Realm, 635.

${ }^{28}$ Peter Wright, Spycatcher (New York: Viking 1987).

${ }^{29}$ Andrew, Defence of the Realm, 642.
} 
surveillance of Wilson, still less in any attempt to destabilise his government. ${ }^{30}$ This was followed by an official statement by Prime Minister Margaret Thatcher in the House of Commons on May 6 1987:

"[T]he Director General of the Security Service has reported to me that, over the last four months, he has conducted a thorough investigation into all these stories, taking account of the earlier allegations and of the other material given recent currency. There has been a comprehensive examination of all the papers relevant to that time. There have been interviews with officers in post in the relevant parts of the Security Service at that time, including officers whose names have been made public.

The Director General has advised me that he has found no evidence of any truth in the allegations. He has given me his personal assurance that the stories are false. In particular, he has advised me that all the Security Service officers who have been interviewed have categorically denied that they were involved in, or were aware of, any activities or plans to undermine or discredit Lord Wilson and his Government when he was Prime Minister. The then Director General has categorically denied the allegation that he confirmed the existence within the Security Service of a disaffected faction with extreme Right-wing views. He has further stated that he had no reason to believe that any such faction existed. No evidence or indication has been found of any plot or conspiracy against Lord Wilson by or within the Security Service.

Further, the Director General has also advised me that Lord Wilson has never been the subject of a Security Service investigation or of any form of electronic or other surveillance by the Security Service." 31

\footnotetext{
${ }^{30}$ Andrew, Defence of the Realm, 642.

${ }^{31}$ Reproduced on the Security Service website https://www.mi5.gov.uk/home/mi5-history/the-cold-war/thewilson-plot.html (accessed August 15 2013)
} 


\section{Critiquing the critique}

There are two analytical approaches to take in responding to this critique: the first is the style and framework of the dismissal of a conspiracy and the second is the evidence of a plot of some sort actually existing. The first rests on the repeated allegations that Wilson was paranoid.

\section{Wilson's [paranoid] character}

Peter Wright uses Wilson's character and associates to paint him as a KGB agent while Andrew uses similar material to paint Wilson's allegations as not worth taking seriously. In fact much of the chapter on the 'Wilson Plot' is a record of Wilson's character flaws rather than an examination of the plot allegations themselves. ${ }^{32}$ Harry Kissin mentioned previously, is discussed as an associate of Wilson's but has little relation to the issue. Apart from Kissin passing on tidbits of political gossip to prostitutes (pieces of information which would have been unlikely to damage the government or national security) the purpose of this section is unclear unless it is to set up Wilson's character as suspect. $^{33}$

With regard directly to Wilson's paranoia, it has to be seen in the context of the time. Wilson's overly suspicious nature may have been a personal feature but the UK was experiencing a paranoid political style in the 1970s in which belief in plots and parallel networks of one kind or another was rife in state and government (official paranoia) and in parliament and the media. ${ }^{34}$ This 'paranoid style' ${ }^{35}$ in British politics was influenced by real factors: the massive and illegal US bombing campaigns in Vietnam and Cambodia, the right wing military coup in Chile which destroyed the democratic

\footnotetext{
${ }^{32}$ Christopher Andrew, The Defence of the Realm. The Authorised History of MI5 (London: Penguin, 2009), $632-33$.

${ }^{33}$ Further, 'Wilson's mental and physical decline was accompanied by, and may partly explain, his increasing tendency (long present in more muted form) to conspiracy theory.' Andrew, Defence of the Realm, 637.

${ }^{34}$ Francis Wheen, Strange Days Indeed (London: Fourth Estate, 2009), 301-03; Stephen Dorril, "So was Wilson right to be 'paranoid' about being spied on?" Daily Mail April 18, 2010. See also Bernard Donoughue's diary entry for February 5 1976: 'HW [Harold Wilson] has revealed a knowledge of some affairs which could only come from some sort of bugging, since I had discussed it with only one discreet person, either in my room or on the phone. Kissin had earlier warned me that my room - which was once George Wigg's - was bugged. I had dismissed that, and tried to resist the kind of paranoia which surrounds HW and Marcia. But the evidence is growing. The Cabinet Office is of course the centre of intelligence activities.' Bernard Donoughue, Downing Street Diary (London: Jonathan Cape 2005), 656-57.

${ }^{35}$ Richard Hofstadter The Paranoid Style in American Politics', Harpers, November 1964 http://harpers.org/archive/1964/11/the-paranoid-style-in-american-politics/7/ (accessed November 23 2013)
} 
government of Salvador Allende (a Labour Party delegation had visited Chile in 1972 and Allende had expressed his desire to move to a moderate non-bureaucratic democratic socialism but also his concern about opponents to this. His downfall shocked the Labour Party ${ }^{36}$ ), the right-wing military coup in Greece in 1974, the Watergate scandal and resignation of Richard Nixon and subsequent revelations about CIA activity as a result of the Congressional inquiries conducted in 1975 into the conduct of intelligence agencies and the removal of Australian Labour Prime Minister Gough Whitlam's government in 1975 by the British appointed Governor General of Australia in suspicious circumstances. These activities confirmed left and liberal critics in their belief that in the cause of Cold War realpolitik and the protection of right wing politics security services would if necessary demolish democracy. For the right, the oil price rises of 1973, industrial militancy and the defeat of the Conservatives in the British General election of 1974, the left-wing military coup in Portugal which let loose left wing nationalist guerrilla movements in the now liberated colonies of Angola and Mozambique, terrorism by the PLO and the defeat of South Vietnam by Northern forces in 1975 confirmed their belief that there was a crisis of democracy or governability in Western states and that communism was gaining the upper hand in strategic terms in world politics. This right wing paranoid style will be discussed further below.

Indeed such was the paranoia at the time that when a book was later produced by two journalists attempting to examine the Wilson plots one former Cabinet Minister thought that the book itself had been subject to dark forces:

'Though the two journalists might have started out wanting to expose Harold Wilson's fears about the security services they ended up being taken over by the Civil Service, and maybe the security services themselves, and used to discredit Harold further. He is made to look utterly ridiculous. It is hard to make sense of it all., ${ }^{37}$

Further, as Andrew himself relates, in his second term of office from 1974-76,

\footnotetext{
${ }^{36}$ Mark Phythian, The Labour Party, War and International Relations (London: Routledge 2007), 79-80.

37 Tony Benn, Conflicts of Interest. Diaries 1977-80 (London: Arrow 1991), 273, entry for February 11978. Indeed, Benn's own telephones were being tapped in the 1970s. Jad Adams, Tony Benn. A Biography (London: Biteback 2011), 348.
} 
'Wilson's suspicions about the Security Service were inevitably strengthened by his briefings on the sensational FLUENCY investigations into Hollis and Mitchell [former senior Security Service managers suspected of being KGB agents]. The impact on Wilson was all the greater because during his first term as prime minister he had not been told about the investigation of Hollis - despite the fact that Hollis had been DG for his first year at Number Ten. ${ }^{38}$

In fact if this is added to the leaking against Wilson (discussed below) his paranoia does not appear without foundation. And ironically Wilson's long term suspicions about bugs in Number Ten were found to be accurate, according to Andrew's own research. MI5 had in fact placed listening devices in the Prime Minister's study, the Cabinet Room and the Waiting Room during the period 1963-1977 with the exception of a few months after Harold Macmillan left office in 1963. 'In all, the equipment monitored the most sensitive areas of Downing Street for around 15 years. It was finally removed on the orders of James Callaghan in about 1977, the year after he took office. The files do not make it clear whether Prime Ministers Heath and Wilson knew there were surveillance devices in No10.' Andrew wished to have this revealed in the authorised history but was blocked. ${ }^{39}$ Andrew did not think it buttressed the Wilson plot allegations but MI5 clearly disagreed, since it does undermine the idea that Wilson was needlessly paranoid.

\section{Plotters and networks in the 1970s: the establishment, MI5 and Wilson}

As mentioned previously, paranoia wasn't only exuding from Wilson's office. As journalist Barrie Penrose relates: "Our establishment, from the intelligence services down to parts of Fleet Street, were paranoid about the threat of communism. So paranoid it seems, they were prepared to believe a prime minister of Britain was an active Soviet spy." ${ }^{40}$ Voices on the right believed Wilson was moving the country towards communism, including General Walter Walker. Walker had been the Commander in Chief Allied Forces, Northern Europe 1969-72. Following his retirement he expressed himself

\footnotetext{
${ }^{38}$ Christopher Andrew, The Defence of the Realm. The Authorised History of MI5 (London: Penguin, 2009), 634.

39 Jason Lewis and Tom Harper, 'Revealed: How MI5 bugged 10 Downing Street, the Cabinet and at least five Prime Ministers for 15 YEARS,' Daily Mail April 18, 2010.

${ }^{40}$ Brian Wheeler, 'Wilson: the secret tapes' BBC News March 9, 2006 http://news.bbc.co.uk/1/hi/uk_politics/4789060.stm (accessed August 10 2013)
} 
politically, arguing about "the Communist Trojan horse in our midst, with its fellow travellers wriggling their maggoty way inside its belly." With regard to Northern Ireland it "should now be declared a proper operational area, or even war zone, in which would-be murderers caught carrying or using arms would be subject to summary trial and execution." ${ }^{41}$ According to David Stirling, founder of the SAS, the left had a 'steady encroachment on the public enterprise system, together with the forcing of trade union members on to the executive board of companies' and was a 'realizable threat of a magnitude this country has never faced before.' Stirling was also publicly arguing for some kind of parallel 'volunteers' organisation to be in place in case of a 'crisis. ${ }^{, 42}$ Others were directly urging for some sort of intervention, including Brian Crozier a right wing journalist with connections to the security services. Crozier engaged in anti-communist propaganda and briefings and openly talked of the benefits of military coups in talks to British army officers. After a talk at an army staff college he received a letter from the Commander saying 'Action which armed forces might be justified in taking, in certain circumstances, is in the forefront of my mind at the moment, and I do hope we may have the chance of carrying the debate a stage further. ${ }^{, 43}$ One of Crozier's friends was Charles Elwell who until 1981 was head of MI5's counter-subversion section. Elwell 'instructed his officers to monitor the activities of trade union leaders, as well as the National Council for Civil Liberties and the Campaign for Nuclear Disarmament.' ${ }^{44}$ This attitude was redolent of an authoritarian culture among certain MI5 officers, not just Peter Wright, and they allegedly regularly leaked material against Wilson to the UK satirical magazine Private Eye. ${ }^{45}$ The views of such actors can be characterised as conforming to Richard Hofstadter's paranoid style of politics. Indeed they match two of his three points about 1960s paranoid style right wing US political beliefs: firstly 'that top government officialdom has been so infiltrated by Communists that American policy, at least since the days leading up to Pearl Harbor, has been dominated by men who were shrewdly and consistently selling out American national interests.' In British terms this matches the idea that Wilson headed a

\footnotetext{
${ }^{41}$ Obituary of General Sir Walter Walker Daily Telegraph, August 132001.

${ }^{42}$ Alwyn Turner, Crisis? What Crisis? Britain in the 1970s (London: Aurum 2009), 128. See also Stephen Dorril and Robin Ramsay 'Wilson, MI5 and the Rise of Thatcher. Covert Operations in British Politics 197478,' Lobster 11 (1986) http://www.lobster-magazine.co.uk/issue11.php (accessed August 5 2013)

${ }_{43}$ quoted in Francis Wheen Strange Days Indeed (London: Fourth Estate, 2009), 256-57.

${ }^{44}$ Richard Norton-Taylor, .Obituary: Brian Crozier', Guardian August 92012.

${ }^{45}$ David Leigh,The Wilson Plot (London: Heinemann 1988), 274; Wheen, Strange Days Indeed, 264.
} 
communist cell in the Labour Government. Second that, "the country is infused with a network of Communist agents.' This is seen in the idea that the unions in the UK were infested with communists or crypto-communists aimed at controlling British foreign policy. ${ }^{46}$

These opinions were part of a wider culture of parallel authorities being urged or created by the right. Former MI6 officer George Kennedy Young and Ross McWhirter set up Unison, an organisation aimed at providing some kind of civil assistance in time of crisis and David Stirling established GB75, (funded by arms dealer Geoffrey Edwards). Lobster writers Dorril and Ramsay think these were in fact part of a British intelligence operation along the lines of that being conducted in Northern Ireland.) Both Unison and GB75 accused each other of being militaristic and both stated that they were just in existence for an emergency. ${ }^{47}$ Civil Assistance then arose from Unison. Led by Walter Walker, it claimed it would stand ready if needed in a civil emergency, although there was no question of this being an insurrectionary militia and it would not be armed. ${ }^{48}$ Joining Civil Assistance, Unison and GB75 were other emergency bodies such as Red Alert, and the British Military Volunteer Force composed of or supported by right wing army officers, industrialists, and discontented middle class individuals. These groups either faded, closed or reformed. No group had major support, despite Walker claiming 100,000 for Civil Assistance. ${ }^{49}$

The biographer of Airey Neave (A Conservative MP involved in intelligence networks and a Shadow Secretary of State for Northern Ireland before his murder by the terrorist group the Irish National Liberation Army) argues with regard to both overt and covert manoeuvring in this period: 'These could be seen as the unconnected efforts of right wingers eager to save their country from the depredations of the left, but so many of the projects seemed to be linked to people who had been

\footnotetext{
${ }^{46}$ Richard Hofstadter The Paranoid Style in American Politics', Harpers, November 1964 http://harpers.org/archive/1964/11/the-paranoid-style-in-american-politics/7/ (accessed November 232013 )

${ }^{47}$ Stephen Dorril and Robin Ramsay 'Wilson, MI5 and the Rise of Thatcher. Covert Operations in British

Politics 1974-78,' Lobster 11 (1986) http://www.lobster-magazine.co.uk/issue11.php (accessed August 5 2013)

; Leigh The Wilson Plot, 221-24; Dominic Sandbrook, Seasons in the Sun: The Battle for Britain, 1974-1979

(London: Penguin 2013).

${ }^{48}$ Obituary of General Sir Walter Walker Daily Telegraph, August 132001.

${ }^{49}$ Stephen Dorril and Robin Ramsay 'Wilson, MI5 and the Rise of Thatcher. Covert Operations in British

Politics 1974-78,' Lobster 11 (1986) http://www.lobster-magazine.co.uk/issue11.php (accessed August 5 2013)
} 
involved with MI5 or MI6 that a conspiracy theory did not seem to be far-fetched. ${ }^{50}$ By 1970 these right wing networks had converted their energies to getting Margaret Thatcher elected as head of the Conservative Party. ${ }^{51}$

However if these views and organisations were the public face of the unorthodox right, the issue of what might have been taking place in secret is evident. Here we only have the flickering signs from Colin Wallace about a military intelligence operation known as Clockwork Orange. Initially this was a project working from the Army's Information Policy Unit which aimed at sewing dissension within republican and loyalist paramilitary groups by spreading disinformation. But in the heated atmosphere of Northern Ireland in the 1970s - where it seemed the British state was on the back foot in the face of the campaign by the Provisional IRA that had spread to the mainland - Wallace's operation, after being taken over by MI5, was tasked with spreading black propaganda rumours against both the Heath and Wilson governments because they were failing to adopt a hard line to Northern Ireland. Wallace expressed opposition to these activities and was forced to resign. ${ }^{52}$ After years of denial or no comment the British government admitted in 1990 that there had been a unit at army Headquarters in Northern Ireland, Wallace had worked for it, and that it had been an information and - in effect - an intelligence operation, (although the government stated that the unit had not been involved in smearing the Wilson government). ${ }^{53}$ This raises the question of the activities of MI5 itself.

\section{MI5 and Wilson}

It is accepted that MI5 had a long term interest in Harold Wilson. A file was opened on him in the 1940s after he had travelled to the Soviet Union and developed links with those involved with trade in Eastern Europe. This file gave Wilson the codename 'Henry Worthington.' MI5 had 'never actively investigated' Wilson but preserved the file on him on the orders of Director General Michael Hanley

\footnotetext{
${ }^{50}$ Paul Routledge, Public Servant, Secret Agent. The Elusive Life and Violent Death of Airey Neave (London: Fourth Estate 2002), 270.

${ }^{51}$ Routledge, Public Servant, Secret Agent, 273.

${ }^{52}$ Paul Foot, Who Framed Colin Wallace? (London: Macmillan 1989).

${ }^{53}$ Mr. Archie Hamilton, House Of Commons, January 15 1990, Cols.108-110. See also Paul Foot 'The Final vindication' Guardian, October 22002.
} 
whilst any card index reference to it was removed. ${ }^{54}$ But it appears that a scattering of officers believed this was not sufficient. KGB Major Anatoly Golitsyn who defected to the West in 1961 in a later debriefing stated that Wilson was a long term Soviet agent and that the previous leader of the Labour Party, Hugh Gaitskell, had been assassinated by the KGB to pave the way for Wilson. The then Director General of MI5, Sir Roger Hollis, in 1963 had rejected bluntly the idea of Wilson as a Soviet mole ${ }^{55}$ but this did not convince certain officers in MI5. As Lord Hunt, who conducted an inquiry into the activities of MI5 stated:

'I don't think the group [in MI5] were in any sense evil. They were people on the whole who followed a train of thought: the Russians used to try and entrap everybody, they must have tried with him [Wilson], they must have succeeded. ${ }^{56}$

Faced with the Golitsyn allegations certain MI5 officers became paranoid about Wilson. Peter Wright's former departmental head, Alec MacDonald later stated on television that a small MI5 faction all devoutly believed Golitsyn and his allegations. This faction might have been small but it was evident and surprised London CIA officers with its disloyal remarks about Wilson; one of these operatives stated 'You would never hear CIA officers talking like that in front of foreigners about the President of the United States. ${ }^{57}$ Indeed, they linked across the Atlantic to the head of CIA Counter Intelligence James Angleton 'where the secret world was even more detached from reality. ${ }^{58}$ Angleton's Special Investigation Group probed Harold Wilson and Angleton remained convinced Wilson was a Soviet agent and also believed the smear stories being put out against Wilson by some MI5 agents. ${ }^{59}$ A security 'merry go round' became evident - a classic example of the intelligence failure of a closed cycle of the same information being fed and then formally recycled between the CIA and MI5 to reaffirm initial beliefs. (Later, George Kalaris, the new CIA counter intelligence head, examined Angleton's files and 'was so ashamed at the unacceptable quality of the intelligence

\footnotetext{
${ }^{54}$ Christopher Andrew, The Defence of the Realm. The Authorised History of MI5 (London: Penguin, 2009), 632.

${ }^{55}$ Mangold , Cold Warrior, 85-86.

${ }^{56}$ Lord Hunt, quoted in 'The Plot Against Harold Wilson' BBC 2 broadcast in 2006.

${ }^{57}$ Mangold, Cold Warrior, 75; see also Pimlott, Harold Wilson, 705.

${ }^{58}$ Ben Pimlott, Harold Wilson (London: Harper Collins 1993), 703

${ }^{59}$ David Leigh The Wilson Plot (London: Heinemann 1988), 215-17 and Tom Mangold, Cold Warrior. James Jesus Angleton (London: Simon and Schuster 1991), 280.
} 
he uncovered that he had several dozen of the most egregious examples destroyed as soon as possible. ${ }^{60}$ ) As mentioned, the allegations against Wilson had been rejected by Hollis and this mattered little to a number of MI5 officers. They were presumably strengthened in their belief because Hollis himself later came under suspicion of being a Soviet spy in the fevered atmosphere of the 1970s and 1980s. A large scale investigation into whether there had been penetration of MI5 began (Operation Fluency mentioned previously) which turned MI5 upside down in a fruitless search for a 'super' mole who never existed.

In this fevered context it seems certain intelligence officers took it upon themselves to move against Wilson. Andrew does not cite at all the book by investigative journalist David Leigh which has an in depth examination of the politics and plots of the 1970s surrounding Wilson. ${ }^{61}$ Leigh in return is strongly critical of Defence of the Realm:

'When it comes to the Wilson affair, Andrew's scholarship appears to slip. He repeats insistently the MI5 party line that there never was misbehaviour against Wilson or his ministers by "the Service", and that it was all mere conspiracy theories. Yet he withholds the fact that the cabinet secretary Lord Hunt authoritatively confirmed the central allegation. Hunt, who conducted a secret inquiry, said in August 1996: "There is absolutely no doubt at all that a few, a very few, malcontents in MI5 ... a lot of them like Peter Wright who were rightwing, malicious and had serious personal grudges - gave vent to these and spread damaging malicious stories about that Labour government." ${ }^{62}$

As Leigh argues, the evidence in Andrew's own chapter points to MI5 having a close interest in Wilson, closer than the overall argument of his official history admits and this took extreme form in the (unlawful) activities of a few agents. Before Lord Hunt's inquiry Maurice Oldfield, former head of MI6 and later Coordinator of Intelligence in Northern Ireland had already warned Wilson that an 'unreliable' faction existed in MI5. Wilson then called in MI5 head Michael Hanley who apparently

\footnotetext{
${ }^{60}$ Mangold, Cold Warrior, 307.

${ }^{61}$ David Leigh The Wilson Plot (London: Heinemann), particularly chapters nine and ten.

${ }^{62}$ David Leigh, Review of 'The Defence of the Realm: The Authorized History of MI5' by Christopher Andrew, Guardian October 10, 2009.
} 
confirmed this. ${ }^{63}$ But it was not only MI5 who were leaking against Wilson. Andrew argues that when Wilson thought MI5 was leaking against him it was in fact the retired deputy head of MI6, George Young, an extreme right wing figure who was 'an embarrassment to his former Service. ${ }^{, 64}$ But Young may not have been the only maverick. Dorril in his detailed history of MI6 has Oldfield himself and other MI6 figures leaking against Wilson and others and blaming it on MI5 for various reasons. ${ }^{65}$ There were a number of right wing security service members from MI5 and MI6 who raise questions about the personnel in those organisations, questions which Defence of the Realm brushes past.

\section{Conclusion: the Wilson conspiracy}

Contemporary historians are less sanguine than Andrew on the existence of some sort of (dis)organised conspiracy against Harold Wilson. Wilson's biographer Ben Pimlott thought that some manoeuvring was taking place ${ }^{66}$ and Dominic Sandbrook, hardly a left wing historian, argues that there was something in the idea of a plot and that the allegations of army intelligence officer Colin Wallace - an individual on the fringes of security networks he did not really understand - link in with those of Peter Wright. ${ }^{67}$ As Benn's biographer points out, 'it is not the individual account which convinces, however, but the cumulative evidence. ${ }^{98}$

If the existence of undemocratic manoeuvring against the Wilson government is accepted, the next issue is how seriously to take it. Pimlott argues the plots were ludicrous and paled behind the real scandals taking place such as the investigations and debate over the bribes that architect John Poulson had been paying to Labour councillors across the country in the early 1970s and the turn against

\footnotetext{
${ }^{63}$ David Leigh The Wilson Plot (London: Heinemann 1988), 250 citing journalists Barrie Penrose and Chapman Pincher on the MI5 confrontation; Richard Norton-Taylor Antony Cavendish obituary Guardian January 23, 2013; Gordon Corera, MI6 (London Phoenix 2011), 213-14. Corera's, the most recent book on MI6 up to the contemporary period does not comment on Wilson's behaviour as paranoid.

${ }^{64}$ Christopher Andrew, Defence of the Realm. The Authorised History of MI5 (London: Penguin, 2009), 633.

${ }^{65}$ Stephen Dorril, MI6. A History of Special Operations (London: Fourth Estate 2000), 743-44. This was also part of a conflict at the time between MI5 and MI6 over who had the lead role in Northern Ireland.

${ }_{66}^{66}$ Ben Pimlott, Harold Wilson (London: Harper Collins 1993), 703-04.

${ }^{67}$ Dominic Sandbrook, Seasons in the Sun: The Battle for Britain, 1974-1979 (London: Penguin 2013), 67-75.

${ }^{68} \mathrm{Jad}$ Adams, Tony Benn. A Biography (London: Biteback 2011), 349.
} 
Wilson inside the Labour Party. ${ }^{69}$ Wilson's retirement can in fact be explained normally. ${ }^{70}$ Wheen in his cultural history of the 1970s argues the same. The talk of coups was fantastic, a dream dreamed by a group of right wing media, army and security figures who felt that the country was going to the dogs in the form of the trade unions and communist activists. Their organisation was similarly phantasmagoric. Sir Val Duncan, then head of Rio Tinto Zinc, hosted a dinner in 1975 in which there was a call for a government of national unity. But two journalists he invited were 'supporters of the party whose government he proposed to overthrow' and the meeting was ridiculous, as described by Wheen. ${ }^{71}$ Similarly even conservatives mocked the idea of right wing militias. Despite General Walter Walker taking of having 100,000 supporters, 'Civil Assistance was fatally easy to mock. Journalists wrote of Lambrook-les-Deux-Eglises in reference to Walker's home in Somerset, and in the Telegraph Maurice Weaver fashioned a masterpiece of mockery from the leader's own remarks. Britain survived; Civil Assistance petered out. ${ }^{72}$ In a debate in 2013 concerning Wilson's legacy Douglas Hurd (Private Secretary to Edward Heath 1968-70) made a similar point about those calling for Wilson's removal:

'They were dotty people and what they were planning was dotty and..in the opposition we realised that....these were absurdities... what I think Harold Wilson can be criticised for is caring about them too much. ${ }^{73}$

Possibly. But it might also be argued that right wing figures talking of overthrowing the government might be worthy of at least taking seriously. Bernard Porter makes an important point: 'Many of MI5's own suspicions of German and Soviet plots were like that: quite wrong, but, in Andrew's judgment, right to have been considered seriously before that was known for sure. What the difference is between these and some of the left-wing ideas about MI5 he is so dismissive of is not always clear. ${ }^{74}$ Indeed, what would the reaction have been of historians such as Andrew to a senior army

\footnotetext{
${ }^{69}$ Pimlott, Harold Wilson, 715.

${ }^{70}$ Pimlott Harold Wilson, 721-23.

${ }^{71}$ Francis Wheen, Strange Days Indeed (London: Fourth Estate, 2009), 255.

72 Obituary General Sir Walter Walker Daily Telegraph August 13, 2001.

${ }^{73}$ Quoted on 'Wilson's World' BBC Parliament, broadcast August 272013.

${ }^{74}$ Bernard Porter, 'Other People's Mail' (Review of Christopher Andrew, 'The Defence of the Realm'), London Review of Books 31, No.2, (2009).
} 
officer with left wing sympathies talking about the possibility of a coup? Or a senior trade unionist in, say 1972, organising a meeting with a select group of politicians and journalists and arguing that Edward Heath should to be removed and a national government formed? Or to union activists calling on left-wing former army personnel and trade unionists to form a 'People's Militia' just in case it was required in case of the collapse of public order? Further, since some of the right wing plotting, absurd or otherwise, was coming from figures inside or connected to MI5 this might be expected to have raised eyebrows and led to some sort of further probing.

In the final analysis Andrew's case rests too much on an analysis of Wilson's character flaws or the company he kept and also on Peter Wright's lack of credibility rather than a focus on the wider evidence and allegations. Wilson did not do his own case any favours by producing a welter of allegations to Penrose and Courtiour who then in turn produced a confusing and disorganised book which Penrose later admitted suffered in terms of coherence and argument. ${ }^{75}$ But Wilson and others in Labour circles were not irrational in being concerned about plotting from right wing establishment figures or about the views and the actions of the security services. Even non-conspiracy theorists might find it worrying to have senior figures from industrialists to ex-intelligence officers and journalists talking of 'regime change', and to have intelligence officers within MI5 actively spreading disinformation against Wilson's government. To repeat, these activities were taken seriously in other contexts i.e. when done by the hard left. We may never know the full details of any plotting that took place but there is enough evidence to show that MI5 was itself something of a paranoid organisation in its attitude towards anything viewed as subversive - as long as it arose from the left.

Indeed elsewhere the official history accepts that MI5 spent enormous energy focusing on a few hundred communist subversives (it even mentions MI5 ferreting out a couple of World in Action and This Week documentaries being influenced by Trotskyist producers, ${ }^{76}$ a level of forensic examination which might have been appropriate towards the plotters against Wilson). Much of the book also

\footnotetext{
${ }^{75}$ Barrie Penrose and Simon Freeman, Rinkagate. The Rise and Fall of Jeremy Thorpe (London: Bloomsbury 1996 283). David Leigh also argues that Wilson became lost in conspiracy theories. The Wilson Plot (London: Heinemann), 235. After 1976 Wilson himself then stayed silent about his views on the intelligence services, producing a famously short one page 'chapter' on security in his The Governance of Britain (London: Weidenfeld and Nicholson, 1976), 167-8.

${ }^{76}$ Christopher Andrew, Defence of the Realm. The Authorised History of MI5 (London: Penguin, 2009), 662-63.
} 
implies the Labour Party was something of a risk. Certainly it was the Party itself who first went to MI5 and asked for help in identifying and surveilling communists or fellow travellers within its ranks. That is a decision that Labour must have regretted in retrospect and probably confirmed MI5 at a formal level in its suspicions about Soviet penetration of the Labour Party. But in the febrile crisis ridden politics of the 1970s as Stephen Dorril argues, state security was as paranoid as any other actor. The idea of a coterie of crypto-communists in the media and the Labour Party steering the ship of government towards the rocks of Brezhnevism is as absurd as anything proposed by the JFK conspiracy theorists.

This article has focused on the dismissal of the Wilson plot, highlighting not only the cultural power of the idea which persists in contemporary history, but also the argument that there is still much to be investigated from that time. There is no truth telling pressure for an inquiry or the disclosure of relevant documents from the period, but it seems the 'wilderness of mirrors' of the 1970s still has much to reveal. 